\title{
British Colonization and Development of Black Tea Industry in India: A Case Study of Darjeeling
}

\author{
Sadia Akhtar ${ }^{1}$, Song Wei ${ }^{1,2}$ \\ ${ }^{1}$ Department of History of Science and Technology, School of Humanities and Social Sciences, University of Science and \\ Technology of China, Hefei, China \\ ${ }^{2}$ School of Public Affairs, University of Science and Technology of China, Hefei, China \\ Email: sadia@mail.ustc.edu.cn
}

How to cite this paper: Akhtar, S., \& Wei, S. (2021). British Colonization and Development of Black Tea Industry in India: A Case Study of Darjeeling. Advances in Historical Studies, 10, 215-232.

https://doi.org/10.4236/ahs.2021.104014

Received: October 24, 2021

Accepted: December 5, 2021

Published: December 8, 2021

Copyright $\odot 2021$ by author(s) and Scientific Research Publishing Inc. This work is licensed under the Creative Commons Attribution International License (CC BY 4.0).

http://creativecommons.org/licenses/by/4.0/

\begin{abstract}
In the early 19th century, the black tea demand was much higher in British, thus, the British government paid serious attention to its cultivation and industrial development in their Indian colonies. Darjeeling was one of the famous places among the Indian colonies, where the tea plantation, cultivation, and industry were initiated with the establishment of British colonization. The black tea produced in Darjeeling had splendid flavored and built its demand in the world tea market. Thus, Darjeeling black tea spread widely and had an influential effect on the market economy of India. Herein, we highlight the impact of British colonization on the development of black tea industry and processing technology in Darjeeling. The crucial factors that flourish the black tea industry in Darjeeling are explored in detail. The tea plantation in Darjeeling was established due to a favorable agro-climatic situation and specific soil characteristics. The factors initiated by the British colonial government including tea processing skills and technologies, infrastructure development, and land and labour availability have enabled the tea industry to extend its market worldwide. This study enlightens the development of the black tea industry in Darjeeling during the British era and offers new insights for the historian.
\end{abstract}

\section{Keywords}

Black Tea Industry, British Colonization, Processing Technologies, Darjeeling, Labour Availability

\section{Introduction}

In the 17th century, Portuguese and Dutch introduced the tea-drinking habit in 
Britain. Green tea was consumed by the upper-class and was considered a medicinal luxury during that time. While in the early 18th century, black tea was produced for the first time in China and had a long preservation time which can be easily transported to faraway countries. After the trading of black tea to Britain, the black tea slowly trickled down to the middle and lower classes and became a national custom within a short time (Ellis, Coulton, \& Mauger, 2015). Thus, European companies increased the demand for black tea during that time (Saberi, 2010). The black tea was imported from China to Europe, and the Chinese received silver in its return, which was draining their Treasury coffers (Sharma, 2006).

In 1757, the British East India Company (EIC) controlled the West Bengal of India. After the control of power in various places of India in 1834, the British EIC tried the experimentation for tea plant cultivation in their colonies (Rose, 2010). On the other hand, the company paid for the Chinese tea with opium which was produced in northeast India (West Bengal). The growing addiction to opium in China caused the Opium Wars (i.e. 1839-1842 and 1856-1860). Therefore, the British were worried about losing their sources and realized to find somewhere within their Empire to grow the tea plants. Hence, the EIC started to look for places to grow tea and initiated commercial tea cultivation in various places in the Indian subcontinent (Dubrin, 2012). Among those places, Darjeeling was the extreme north of India's West Bengal State in the Himalayan foothills where tea cultivation experimented and the commercial tea cultivation was started after the First Opium War (Bhattacharya, 2007).

Koehler (2015) explained the reason for tea cultivation in Darjeeling as: "the Assam tea gave quantity but not quality to the British EIC," therefore, the commercial tea production was initiated for good quality in Darjeeling. The Darjeeling provided the world-famous aroma and flavored black tea that was impossible to replicate. In addition, the high-quality Darjeeling black tea was produced due to the environment and soil of Darjeeling and has been traditionally appreciated more than the other black teas as well as known as "champagne of teas". The Darjeeling black tea is currently produced in 87 gardens (Figure 1) at different altitudes up to 2000 meters (Bhutia, 2016). The total production of black tea in Darjeeling is about 8 - 11 million kilograms each year and its demand in the UK, Germany, USA, Japan, and other EU countries was increased (Khawas, 2011).

The growth and early history of Assam tea have been discussed by many scholars (Behal \& Mohapatra, 1992; Suparna Roy, 2011; Sen, 2010; Sharma, 2006, 2009). Although, relatively few authors have discussed Darjeeling black tea (Besky, 2014; Bose, 2018; Tirkey, 2005). Besky (2014) has studied the labour condition and justice of the labours in Darjeeling gardens, while Bose (2018) wrote a very short report on early tea industry development in Darjeeling, and Tirkey (2005) focused on the geographical indication of Darjeeling tea. Considering these studies and limitations, the current study aims to briefly highlight the impact of the British colonization on the development of the black tea industry 

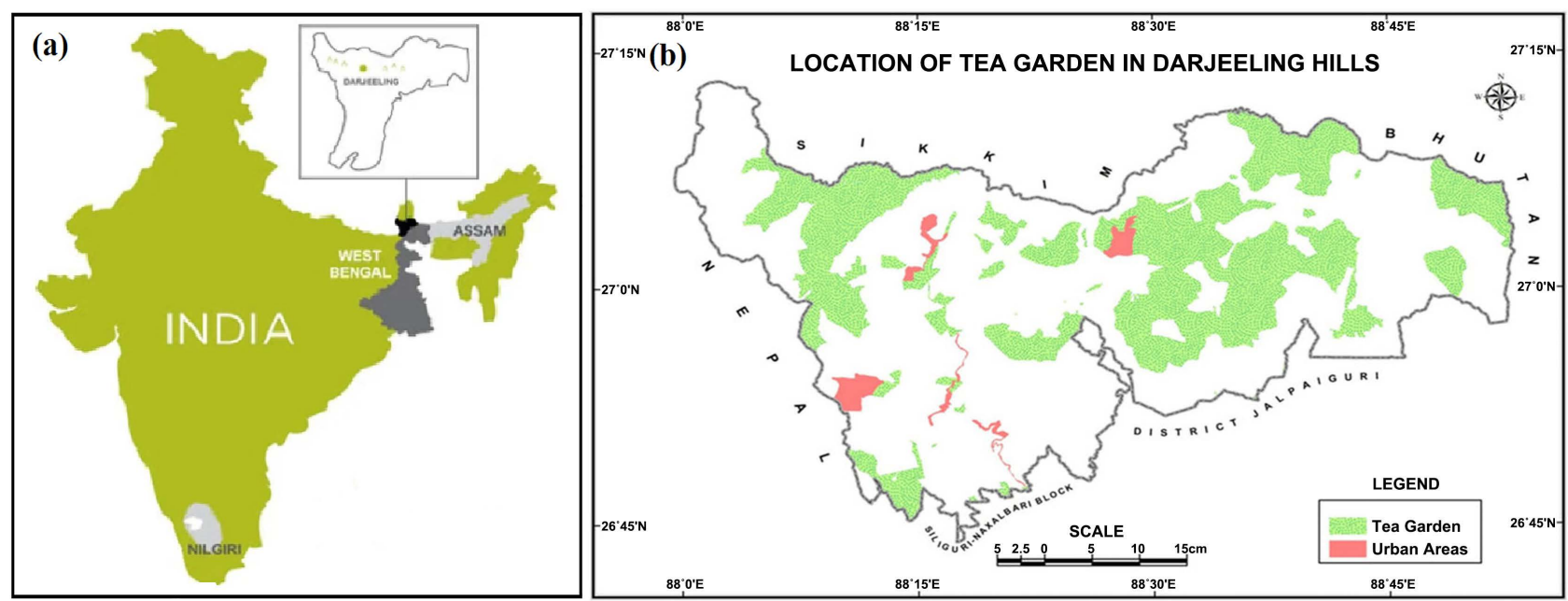

Figure 1. (a) Location of the study area (Darjeeling); (b) tea cultivation places in Darjeeling. source: (Bhutia, 2016).

in Darjeeling. Moreover, it will further enlighten the crucial factors including the labour and land availability, processing skills and techniques, and infrastructure development during the British era for black tea development in Darjeeling. The current research will be helpful for the historian regarding understanding the historical development of famous Darjeeling black tea during the British period in India.

\section{Research Questions}

The below questions are adopted in the current research study to investigate the purpose of the study.

1) How the British imperialism initiated the cultivation and industry of black tea in Darjeeling?

2) How the black tea processing technology was implemented for the development of the tea industry?

3) How did labour migration and land provision policies help to shape and flourish the black tea industry in Darjeeling?

4) How did the infrastructure development help in the black tea industry development in Darjeeling?

\section{Research Methodology}

To address the above-mentioned research questions, the data is explored and analyzed via extensive search. Herein, the qualitative research approach is performed using a variety of primary and secondary sources from integrated fields including books, publications, journals, historical documents, notes, reports, letters, and historical pictures. Various notes regarding Darjeeling such as Hooker's notes, Robert Fortune's notes of 1852, and A. Planter's notes of 1888 were used in this study. Similarly, letters about Darjeeling's colonization including Lieutenant Colonel G.W.A. Lloyd of 1829 were used, while several other valuable notes and reports were also used in the current study. The statistical data was 
gathered from the old records such as W.W. Hunter of 1875 and Bengal district gazetteers of 1907 and 1947. The information about Darjeeling black tea industry during the British period was collected from these sources and the findings are summarized.

\section{Discussion}

\subsection{Darjeeling Colonization and Development of Tea Cultivation}

Historically, Darjeeling is situated in the Singalia range of the eastern Himalayas and belonged to Sikkim and Bhutan (see Figure 1). Before the 19th century, Darjeeling was part of Sikkim Raj and the Raja of Sikkim had been involved in unsuccessful warfare against the Gorkhas (Kingdom of Nepal). Thus, Gorkhas constantly made inroads into Sikkim and conquered Teesta and Terai regions during the early 19th century. On the other side, the British were trying to protect the northern frontier Sikkim from the attack of Gorkhas. The Anglo-Gorkha War was fought between the Gorkhali army and EIC from 1814-1816, as a result under the Treaty of Sugauli, and one-third of Nepal's was given to the British in 1816. Nepal also ceded all those territories that the Gorkhas had occupied from the Sikkim's Raja to the EIC. In 1817, under the "Treaty of Titalia" the EIC returned the land area between the Mechi and Teesta to the Chogyal of Sikkim and guaranteed his sovereignty. In 1828, a dispute once again arose between Nepal and Sikkim, Governor-General William Bentick sent two officers Mr. J.W. Grant, and Captain Lloyd to restore normalcy. Captain Lloyd came to the hills and was attracted by the environmental and geographical location of Darjeeling (Rai, 2012). Lieutenant Colonel G.W.A. Lloyd wrote a letter to Lord William Bentinck, Governor-General on 18th June 1829 and addressed Darjeeling as "this position would be a check by commanding an entrance into Nepal and Bootan". Lloyd wrote as "I have little doubt the advantages it possesses as a Sanitarium". Mr. Grant, the Commercial Resident at Malda gave several notices to the Governor-General and highlighted the numerous advantages about promised the establishment of a Sanitarium at Darjeeling. In response, the Governor-General requested the Deputy Surveyor General (Captain Herbert) and Mr. Grant to explore the tract of the Sikkim hills for the company. They reported back to the Governor-General in which Captain Herbert strongly supported the occupation of the track for a military position as the key of a pass into the Gorkha territory. After their report, the company's Court of Directors was hoped to convince the local Government which is practicable and advisable to create a permanent Cantonment for a European Regiment to establish a Sanitarium at Darjeeling. Colonel Lloyd was instructed for the negotiation with the Sikkim's Raja for the cessation of Darjeeling to the British Government. They offered an equivalent land or money that was more reasonable. After that, in February 1835, the East India Company started direct rules on Darjeeling by Deed of Grant from Rajah of Sikkim. The British occupation of 640 sq. miles area of Darjeeling from the Raja of Sikkim was made complete during 1850 (Dozey, 1922). 
Several significant reasons motivated the EIC towards the Darjeeling colonization. However, the main reason was its geopolitical status, as Darjeeling was a part of Sikkim through which the British commercial ties were closely connected. It would also safeguard the northern Indian border from India Sikkim Bhutan and China. It is also commanded the historic Kalimpong-Lhasa trade route which was the shortest route to Tibet. The control of Darjeeling motivated the traders and increased the trade volume with Tibet, Nepal, Bhutan, and Sikkim (Sarkar, 2014). The British were desired to develop a friendly relationship with Nepal which became a driving force behind the acquisition of Darjeeling. The British wanted to recruit Nepali or Gorkha soldiers in the Indian Army through Darjeeling. The Gorkhas were brave, efficient, and trustworthy people (Rathaur, 2001). Moreover, the pleasant environmental condition attracted the British to establish the Sanitarium and control it.

In January 1834, the East India Company selected Lord William Bentinck to set up a tea committee for the investigation and recommendations of the most suitable areas for tea cultivation. Lord William Bentinck remarked on the prospect of growing tea and considered the question of importing seed and plants from China and to decide the most favorable localities for growing them" (Martin, 2011). The Tea Committee decided to send Secretary G. J. Gordon to China to acquire tea seeds, tea-making technology, and experts who were familiar with the cultivation of the tea plants. He was returned with 80,000 Bohea tea seeds (known as Wuyi tea, a type of black tea seeds). The seeds were brought to Calcutta and transferred to the Botanical Gardens for germination under the supervision of Dr. Nathaniel Wallich (Hall, 2000).

In 1839, when the company started direct ruling in Darjeeling, a civil surgeon Dr. Archibald Campbell was transferred from Kathmandu and appointed by the British government as a superintendent of Darjeeling. Previously, he was working under the famous naturalist and ethnologist Brian Houghton Hodgson in Kathmandu, the Campbell was inspired by him to care for the native flora and fauna (Koehler, 2015). Therefore, in 1841, he took the first initiative and brought some China tea seeds (i.e. Camellia sinensis) from Kumaon and planted those seeds in his garden, known as the Beechwood which was located at 2134 meters above sea level. The climate and favorable weather boost up the tea growth in his garden and he was succeeded in tea cultivation. He proved all wrong opinions, as Sir Joseph Hooker (founder of geographical botany) and Charles Darwin's closest friend believed that the tea will not grow in Darjeeling due to the too much height and moisture with too little sun. They also assumed that the summer heat is not sufficiently strong to ensure fine flush (Maude, Davison, \& Haswell, 1869). These experiments were also performed by several others, such as Captain Samler, Mr. James Grant, and Dr. Withcombe of the civil service. As a result, the plants' growth was healthy and vigorous which gave them many promises of the experiment's success. In 1848, Mr. Martin planted several tea plants of both China and Assam varieties that were established at 
Kurseon and Pankhari and succeeded admirably (Ahuja, Gulati, Singh, Sud, \& Boruah, 2013).

Mr. Jackson says in his report on Darjeeling in 1852 as "I have seen several plantations in various stages of advancement, both of the Assam and China plants and I have found the plants are healthy and vigorous, showing that the soil is well adapted for the cultivation. In the garden of the Darjeeling Superintendent, Dr. Campbell, in the more extensive plantations of Dr. Witheoombe, the Civil Surgeon, and Major Crommelin, of the Engineers, in a lower valley called Lebong, the same satisfactory result has been obtained: the leaves, the blossom, and the seeds are full and healthy: the reddish olay of the sides of the hill at Lebong seems to suit the plant better than the black loam of Darjeeling. This has been the result at and about Darjeeling itself, at a height of 7000 feet; but the opinion of Dr. Hooker and of others competent to judge seems to be that there is too much moisture and too little sun at Darjeeling to admit of the cultivation on a large scale booming remunerative: this objection, however, does not apply to the lower sites of Pankhabari and Kurseong, where a plantation of both tea and coffee has been established by Mr. Martin, and the plants are now in a lightly-thriving condition. In this tract of country, between the Morung and Darjeeling, every variety of elevation and aspect is to be found, and there seems to be little or no doubt that tea cultivation in that tract would answer" (Lss, 1907).

All these plantations were only experimental plots, however, the Darjeeling tea industry was established on a wide-range scale from 1856, especially on the lower slopes, because it was believed that the elevation of Darjeeling was too high and not good for tea production (Kati, 2015). The Company established several tea nurseries and began to spread plants for individuals as well as small enterprises, opening up land and clearing plots for tea gardens in Darjeeling. The tea companies have adopted the structural layout and the management policies of tea estates from the experience of tea plantations in Assam. Nepalese laborers refurnished the Himalayan foothills by cutting and burning the small brushes. They have cut the lateral roots of big trees, thus, those trees were fallen on the ground due to their heavyweight. The rocks and roots were moved far away and trenches were made smooth and the nurseries were laid out rectangular beds some five feet wide and in between paths. The seeds were placed in nurseries about an inch deep, and from four to nine inches apart, while great care was taken in shading, manuring, and watering. The shades were usually done through the raised tatties of grass and mats. These shades were made of thin thatch spread on bamboo frames some five feet high. All weeds were removed by hand from the planted seed in the nursery, and the seedlings were left in the nursery for six to eighteen months. In these gardens, four to six feet distant from the nearest plant in any direction was kept, while the lines were formed, and the distances were decided. The ten inches deep and at least a foot wide holes were dug for the plants; hence, the land was ready for the plants. The China type of 
bush was preferred at high elevations where the climate is severe. While in lower elevation, the hybrid variety (combination of Assam and China verity) was cultivated (Ukers, 1935).

The British Government offered the land to the investors for the cultivation of tea plants under reasonable terms and conditions. Considering the government rules, only 40 percent of forest land will be used for the tea plant cultivations, while the rest will be remained as usual. The British government provides a mound of tea seed to the natives to promote tea cultivation. As a result, in 1856, the tea plants had been sown at Kurseong by Mr. Smith, at Takvar to the north by Captain Masson, and between Kurseong and Pankhabari by Captain Samler, at Hope town and Canning plantation by the companies attracted to these locations. At this time the tea plantation was developing at a rapid speed. In the same year, Kurseong and Darjeeling Tea Company opened the Alubari tea garden and another garden at Lebong spur was opened by the Darjeeling Land Mortgage Bank. By 1857, six nurseries were built in which a ton of seeds were sown. While in 1859, Dr. Brougham opened the Dhutaria garden, and between 1860 and 1864, the Darjeeling Tea Company established four gardens at Ging, Takdah, Ambutia, as well Phubsering and at Badamtam and Takvar by the Lebong Tea Company (Rai, 2015). Several other tea gardens including Pandam, Steinthal and Makaibari were also established during this period. At the same time, the East India Company considered the Tarai region for the establishment of the tea industry. Therefore, the first garden was opened in 1862 at Champta near Khaprail by Mr. James White, who also previously established one of the largest tea gardens at Singell near Kurseong. In 1866, several tea estates were initiated in the Tarai region of the Darjeeling district (Lss, 1907). After his experimentations, Sir Joseph Hooker says in his notes as "It has been tried on a large scale by Dr. Campbell at his residence (alt. 7000 feet), but the forest and snow of that height injure it, as do the hailstorms in spring" while about the lower elevation, Lebong thousand elevation below Darjeeling he wrote as follows "the tea-plant succeeds here admirably and might be cultivated at great profit, and to be of advantage in furthering trade with Tibet" (Hooker, 1891).

The soil and favorable environment of Darjeeling made possible the flourishment of tea gardens and encouraged the rapid growth of the tea industry. All these gardens had been established and were situated at elevations ranging from around $150-2100 \mathrm{~m}$ above sea level, with an annual rainfall of 70 to 150 inches. Moreover, the annual temperature of Darjeeling mainly ranged from $53^{\circ} \mathrm{F}$ to 75 ${ }^{\circ} \mathrm{F}$, and during winter in higher elevation temperatures dropped to $40{ }^{\circ} \mathrm{F}$. The Darjeeling tea soil is rich and loamy and the average level of carbon in Indian tea-growing areas is less than 1 percent, although it is much higher in the Darjeeling area (Maude et al., 1869). The tea plant growth rate in Darjeeling is slower than the Assam due to the climate variation that makes it high quality and more superior. The specific soil characteristics, cool, constant mist, damp climate, as well as the high elevation of Darjeeling combined produced a muscatel 
flavor profile typical of Darjeeling black tea that created its demand in Europe. Therefore, the British government tried to extend the industry and gain more profit. In 1866, there were only 39 tea estates with 10,000 acres under cultivation, and an outturn of over 433.000 lbs. The statistics show a significant increase in Gardens, areas under cultivation, and production as shown in Table 1. There were 142 gardens with 63,059 acres under cultivated, and an outturn was increased by 23,721,500 lbs in 1940 (Malley, 1999). Table 1 illustrates the advances which have been made from 1866-1940 that showed a significant improvement in tea gardens, area of cultivation, and production.

\subsection{Labour Arrangement for Industry}

In 1839, no more than 25 families were living in Darjeeling as it was a hill and forest area. Tea is being a labour-intensive enterprise and required appropriate numbers of labour for cultivation, plucking as well as final processing for production (Dash, 1947). Therefore, Dr. Campbell's faced a labour shortage at the beginning for the cultivation of tea at gardens. Thus, he requested a Nepalese

Table 1. Tea production area, number of tea gardens, and output in Darjeeling tea industry 1866-1940.

\begin{tabular}{|c|c|c|c|}
\hline Years & Gardens & Area under cultivation in acres & Outturn in lbs. \\
\hline 1866 & 39 & 10,392 & 433,715 \\
\hline 1867 & 40 & 9214 & 582,640 \\
\hline 1868 & 44 & 10,067 & 851,549 \\
\hline 1869 & 55 & 10,769 & $1,278,869$ \\
\hline 1870 & 56 & 11,046 & $1,689,186$ \\
\hline 1871 & N/A & N/A & N/A \\
\hline 1872 & 74 & 14,503 & $2,938,626$ \\
\hline 1873 & 87 & 15,695 & $2,956,710$ \\
\hline 1874 & 113 & 18,888 & $3,927,911$ \\
\hline 1885 & 175 & 38,499 & $9,090,298$ \\
\hline 1895 & 186 & 48,692 & $11,714,551$ \\
\hline 1905 & 148 & 50,618 & $12,447,471$ \\
\hline 1910 & 148 & 51,281 & $14,137,500$ \\
\hline 1915 & 148 & 45,024 & $20,303,500$ \\
\hline 1920 & 148 & 59,356 & $15,850,500$ \\
\hline 1925 & 148 & 59,356 & $18,732,500$ \\
\hline 1930 & 148 & 59,356 & $20,870,500$ \\
\hline 1935 & 148 & 59,356 & $21,026,000$ \\
\hline 1940 & 142 & 63,059 & $23,721,500$ \\
\hline
\end{tabular}

Source: (Malley, 1999) and (Dash, 1947). 
nobleman namely Shri Dakman Rai to help him to immigrate and bring the labour from Nepal. The importation of labour from Nepal was far simpler and was extremely useful for the tea companies than the system of immigrating indentured labours from the tribal areas of Santhal Parganas and Chotanagpur that were dominant in Assam (Gupta, 1992). Mr. Rai was returned with several immigrants of the Gurkha or Nepalese community to Darjeeling. Dr. Campbell gave grants of freehold lands to Mr. Rai in appreciation for his assistance. The first group of workers was not sufficient for the development and initiation of the industry. Therefore, one of the directors of Darjeeling Tea Company, Mr. Christison had requested to Mr. Rai to bring more labours from Nepal. Mr. Christison promised him to deliver the seeds for the establishment of his tea estate on the lands that were gifted by Dr. Campbell (Christison, 1895).

The Darjeeling attracted the Europeans Entrepreneurs and they established tea estates in a large amount. Then the proper labored recruitment was started by the Sardari system in which the individual gardens sent Sardars once a year to recruit laborers and they were paid Rs.10 each person respectively as recruiting bonus. Every year in the winter season which generally began after the rains in October or November and ended in February, each garden Sardars were sent to Nepal and Sikkim for labour recruitment. This process of recruitment was the best and cheapest way of importing laborers. They brought the whole families as the British were advocating the employment of families rather than individuals. The Royal Commission acknowledged the system recruitment of families instead of individuals and also practiced granting lands for spare-time cultivation. These policies aimed to make the life of tea-garden workers resembled that of the villager and avoided the worst features of town life (Griffiths, 1967). Moreover, the women and children could also become the laborers of gardens as the women were considered to be better puckers and could be plucked the excess tea leaf that was more than double from their pay. Each plantation also provided housing and medical services for immigrant laborers. With the development of the plantation economy in Darjeeling, the proper education system was established for the laborer's children. After being brought families to the tea gardens, they were tied down and became almost like bonded labour. To achieve these strategies a para-military force known as North Bengal Mounted Rifles was kept at the plantations (Sharma, 2003). The population of tea plantation labours jumped from less than a hundred people to twenty-two thousand by 1874. Figure 2 shows the year-wise labour enrollment in the tea industry from 1869-1874. The immigrant laborers were living under the Sardars who were responsible for bringing workers to Darjeeling. The plantations offered labour housing, farmland, and schools for their children, privileges to Nepali families to motivate them to immigrate toward Darjeeling (Besky, 2008). By 1845, Dr. Campbell stated that the plantation industry had attracted 10,000 settlers from Sikkim, Nepal, and Bhutan, who came to work as labourers, woodcutters, builders, porters, and servants for the expanding British hill station (Besky, 2007). 


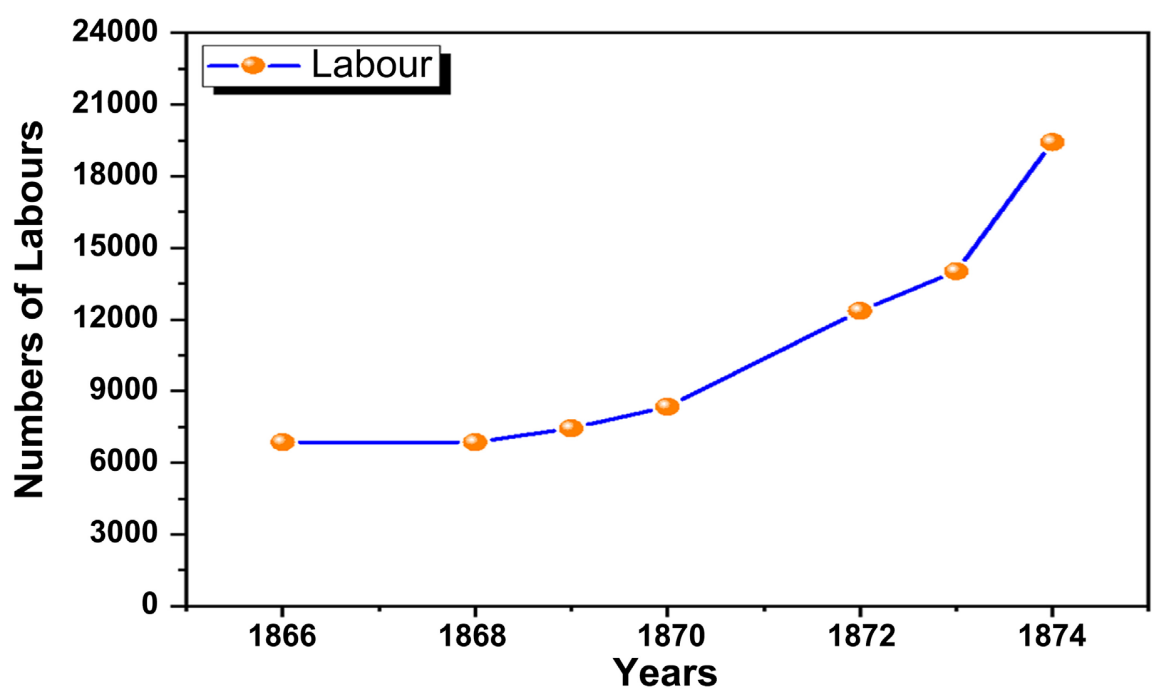

Figure 2. The labour enrolment in the Darjeeling tea industry from 1866-1874. (Source: W. W. Hunter, A Statistical Account of Bengal, Darjeeling and Jalpaiguri, Vol. X, London, and Edinburgh, 1875, p. 165).

\subsection{Provision of Land}

At the initial stage of the tea industry, Dr. Campbell had done some initiatives with the grant policy of lease land for tea at nominal costs in Darjeeling, as it was also the feature of the tea industry in Assam, Duars as well as Terai. After that, the government provided the land for fifty years as farming leases in 1858 at a token rent of eight annas per acre for five years. In 1859, the government provided quite different land tenure rules in Darjeeling such as one manual for planters clarified: "In Darjeeling, the native cultivators have no saleable rights in the soil. In Kangra, the natives dispose of their surplus land or sell their homesteads at simply ridiculous prices (and they almost invariably squander the money as soon as they get it)" (Besky, 2014). It means that the planters who desired to initiate tea plantations in Kangra had to buy the land from local people. The British government categorized Darjeeling and the surrounding foothills as a wasteland. It was including forests and lands, thus the leases for farming and the development of wastelands were more favorable for settlers and policy provided opportunities for those British entrepreneurial who were interested in extractive industries and agriculture.

The tea industry in Darjeeling attracted diverse European entrepreneurs and they gradually converted the land to tea cultivation. These enterprises comprised to a great extent of retired officials including medical, military personnel, and civil as well as entrepreneurs (Bhattacharya, 2012). The 9000 acres of wasteland were sold between 1859 and 1861. In 1861, the British government changed the land policy and announced the fee simple, where the wasteland was treated as heritable property. There was no increase in the land revenue and no grantee to cultivate or clean any specific part of the land in a specific time (Khasnobish, 2016). The Waste Land rules developed a law, where 15 percent of the lease desirable to cultivate the tea plants (Mukherjee, 1976). The Wasteland rules were 
changed in various periods (i.e. 1864, 1882, and 1898) and proved to be favorable and economical for the tea plantation project. The wasteland rules were provided based on a ninety-nine-year lease for a huge part of uncultivated land in Darjeeling during 1882 (O’Malley, 1910). These leaseholds were provided to those who wanted to enhance the quality of the land. According to the wasteland rules, the individuals can transfer the property rights to leasehold. This will make it convenient for the settlers to transfer their land tracts and crops to new owners. Thus, these rules improved the Darjeeling tea plantation landscape.

\subsection{Black tea Processing Technology Development}

The flourishment of an industry without technical development is impossible. Thus, tea processing technologies are crucial to the development of the tea industry. The tea was a new agricultural product and the Europeans were unfamiliar with the processing technology and even they didn't know that the green and black teas are produced from the same plant. Therefore, it was necessary to transmit tea processing skills and techniques from China. The first opium war (1839-1842) was ended through the "Treaty of Nanjing" between China and the British in which the five ports of China namely Canton, Foochow (Fuzhou), Ningpo (Ningbo), Amoy, and Shanghai were opened for the foreign trade with Europe and the British also ceded Hong Kong (Wong, 2007). Therefore, the East India Company got opportunities to transfer the tea seeds, tea cultivation as well as processing skills. The company sent Robert Fortune in 1848 to China particularly to the tea-growing regions (i.e. Fujian and Anhui) to obtain the tea seeds and plants and as much knowledge about the tea production process as possible (Willson \& Clifford, 2012). Robert Fortune was very successful in his mission and collected 20,000 tea plants and seeds as well as convinced several tea farmers from China to go with him to India and assist him in the growing and production of the tea. Thus, Robert Fortune was able to help tea production in India and provided a complete detail of knowledge of the green and black tea process to the East India Company (Fortune, 1852). Dr. Archibald Campbell requested East India Company about the opinion of Robert Fortune on returning from China regarding the suitability of the climate and soil of the hills for the cultivation and manufacture of tea (Koehler, 2015). After that, a large amount of plant from Robert's stock was planted for the commercial scale in Darjeeling. Robert Fortune provided knowledge of tea processing to Dr. Campbell and also transferred to the other planters of Darjeeling.

In the beginning, black tea was produced manually. The tea processing steps were described as follows. The leaves and bud that ought to be picked were consisted of withering tea leaves on bamboo racks, rolling withered shoots by hand and feet, fermentation on the floor, and drying was done in big cauldrons. The last step (sorting) was done by hand by winnowing made tea using fans. The tea was packed in wooden boxes that were made locally (Hathorn, 1863). The tea plantation industry is a labour-intensive industry, therefore, recruitment of large numbers of laborers was one of the biggest problems faced by the planters dur- 
ing the establishment of the tea industry. Besides the strategies adopted for the labours social life improvement, the sanitation, medical treatment, and water supply to the plantation workers were not proper and was a big issue. Therefore, they were used to running away in winter times from the gardens. The managers went around the villages with money in bags to attract the workers and encourage them not to be run away from the gardens but still, the labours were not satisfied. The tea process manually required more time in the rolling process, and need more time and labour. Hand sorting was a clumsy process, therefore, it was necessary to revolutionize the tea industry in India. Besides these, to improve the production of tea plantations and to gain and maintain the market competition with China, the British employed their experience regarding the industrial revolution in tea production regions in India. For example, Davidson and Jackson invented mechanical sorters in 1870, where the leaf was placed in a rotating cylindrical sieve. Moreover, the advance leaves rolling machine was invented by a British mechanical engineer William Jackson in the 1870s. The two or threehorsepower steam engine was required for the operation of this machine that was able to turn out five mounds an hour. It was designed to prepare the leaf for final rolling by hand and it reduced the 75 percent times as compared to hand rolling. In 1874, Lieut.-Col. Edward Money invented the mechanical tea drier machine (Hall, 2000). After the invention of these machines, engineer W. O'Brien Ansell developed and revolutionized the tea manufacturing process in Darjeeling. In the 1880s, he introduced advanced power-driven tea rollers and tea sorting machines (Wallis-Tayler, 1900).

The note written by Planter (1888) discussed the whole process of early black tea processing in Darjeeling during the British colonial period, while in the first step, the tea leaves were picked by the workers in the evening. The two leaves and a bud were selected for picking. After bringing to the factory, these were laid out in the trays and on the floor for withering. Assam and China leaves were kept separate because these need different times of fermentation. The leaves were put out in very thin layers in a dry place. Mostly, the leaves were over withered for the better quality and fairly dark infusion, and then withering the leaves were directly rolled. If pretty teas were required to produce, it was lightly rolled for 20 minutes through the machine. But if strong teas were desired, so leaves were heavily rolled for 40 minutes. After rolling the leaves twice times, it was kept cold before the second roll. The first flushes were needed heavy roll and produced strong teas and for the fine plucking slight rolling for a short time was required. After the rolling, the leaves were shifted for fermentation. In this process, the leaf was spread evenly 2 inches thick, and covered with a thick black cloth. After the fermentation process, the tea leaves were dried traditionally. This process was done through the fire using a big pan, while the small number of tea leaves was stir-fried for a few minutes. However, a large number of leaves were put in at the top of the machine and came out at the bottom during the mechanical process. The time required for this process was about 30 to 40 minutes. Tra- 
ditionally after firing, the tea was usually directly sorted by hand where the leaves were graded according to the leaf size. Then the leaves were passed through the cutting machine using the mechanical process where the size of the large leaves was reduced. After size reduction, the leaves were graded through sifting and sorting machines. The manufactured teas were then packed in the box for selling. Planter further wrote about the packing that after filling the box nearly full, a cloth was put on the top, and gradually tramples it in with his feet until he has got the whole amount in it. Then, another coolie solders up box, and carpenters close. The boxes are marked with garden mark, grade weight, number, and dispatched (Planter, 1888). Figure 3 exhibits the various operation including plucking the leaf, withering it, fermentation on the floor, rolling and drying by machinery, sifting, grading, and packing tea for trade respectively. Moreover, in 1890, the Darjeeling black tea industry was further advanced as W. O'Brien Ansell replaced the old water-wheels with the more modern and effective turbines near the Darjeeling tea estates. He also laid the basis for implanting electrical cables as well as creating connections with Darjeeling tea estates for fast production (Bhattacharya, 2012).

\subsection{Infrastructure Development}

For the growth of the tea industry, it was necessary to link the plains and the hell tracts permanently. Transportation has been considered a fundamental factor in the industrial revolution and business expansion of tea. Therefore, the British government concentrated on infrastructure development in Darjeeling and Lieutenant Napier started to initiate the foundations of the Pankhabari road. After that, this road was found to be too much narrow and steep for wheeled traffic, and later in 1861, a new cart road with an easy gradient was built. This cart

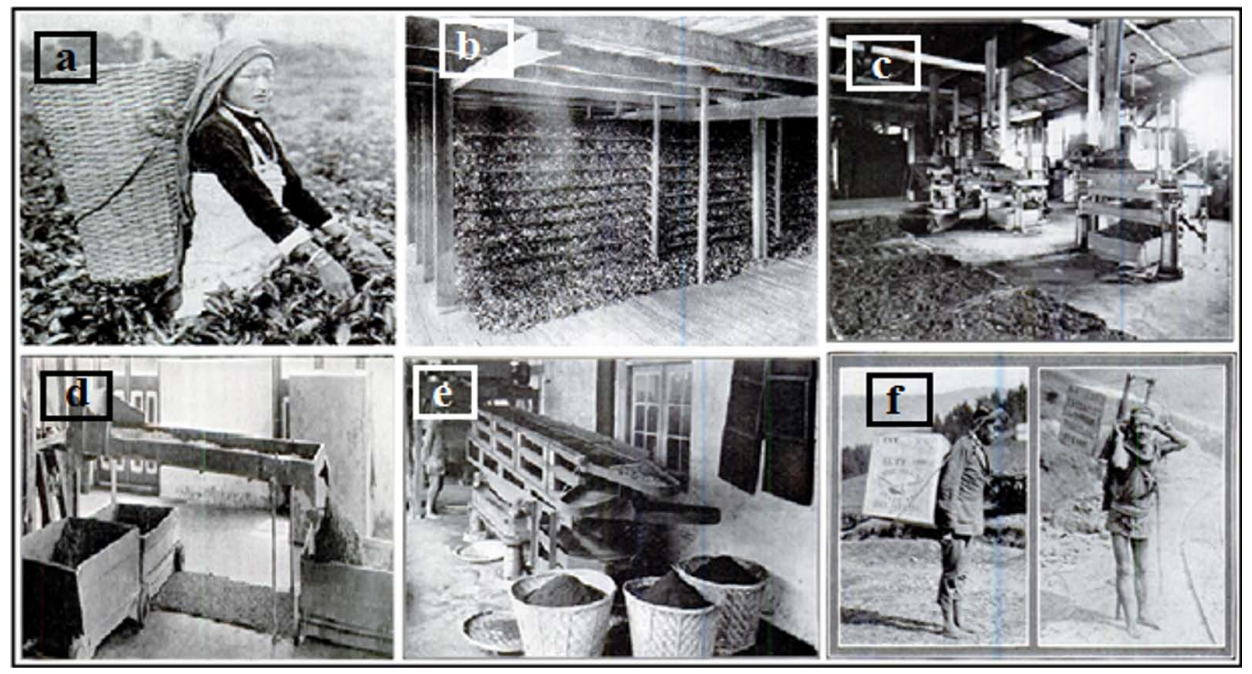

Figure 3. The black tea processing method in Darjeeling tea estate in the late 19th and early 20th centuries (a) plucking the leaf; (b) withering; (c) fermentation on the floor, rolling and drying by machinery; (d) sifting; (e) grading; and (f) packed tea for trade. Source: All about tea (Ukers, 1935). 
road was then linked with the great road built across Bengal with Calcutta as the epicenter of business (Rai, 2015). The road infrastructures promoted the labour movement within tea estates and improved the immigration of labour and the arrival of tea garden machinery to the hills on time.

Although, the need for a railway was initially expressed for the development of the tea trade by the tea industry. For example, Malley discussed as "to get up the hills the stores necessary for the industry and to take down to the sea the products of their toil, the tonga, the old bullock cart, the pack pony, and the human carrier bearing enormous loads on his back were found to be insufficient. The result was an agitation for a railway" (O'Malley, 1907). Maude et al. (1869) claimed in their report on the tea industry in India as: "Tea cultivation is popular with all the hill tribes around Darjeeling, and the women and children gladly take work in leaf picking in the manufacturing season. There is still a good deal of land, I believe, available for cultivation, and the road communication with the plains is much improved. Railway communication, however, is still urgently required to develop fully the progress of the district. The Darjeeling tea is sent to England; it is also used on the spot, and in Bengal. There will no doubt be a market for it in Tibet. It is always a slow process to alter the course of trade an anywhere, and Tibet has always been supplied direct from China". In 1878, an agent of the Eastern Bengal Railway namely Franklin Prestage predicted the significance of a rail link between the hills of Darjeeling and the plains. He reported a detailed scheme to the Government of Bengal and was approved by Lt. Governor Sir Ashley Eden. He pointed out how a railway could easily reduce transportation costs between Darjeeling and the plains areas. On April 8, 1879, he received final approval for his project and formed the Darjeeling Steam Tramway Co. However, the idea of line operating as a steam tramway was uncontrolled on September 15, 1881, therefore, the company implemented the designation of Darjeeling Himalayan Railway Co. (DHR). The establishment of the Darjeeling Himalayan Railway in the last quarter of the 19th century had a deep impact on the social and economic developments of Darjeeling. Its tactical location on the international border covered up the Trans-Himalayan trade especially the Chinese trade via Tibet (Khatun, 2013). Thus, the construction of the Darjeeling Himalayan Tramway Co railway was initially started in 1879 and the work was carried out in a simultaneous process on unconnected sections.

The road and railway construction connected Darjeeling to Calcutta, and it was exported to Europe and Tibet from the Calcutta (Roy \& Hannam, 2013). In the year 1883, the first Darjeeling tea trade was started and due to the special flavor, its demand increased in British especially in Yorkshire. Hence, the development of transportation systems in Darjeeling stimulated commercial expansion, facilitated the division of labour, the industrial revolution, and linked production to markets. The provision of land, labour, and infrastructure resulted in the faster tea production and business of the Darjeeling tea industry and became competitive in quantity and quality with the Assam. 


\section{Conclusion}

The current study provides a fundamental background for the development of the black tea industry in Darjeeling during the British era and briefly explores the factors that boost the development of black tea and enabled it in the world market. Darjeeling was colonized by the British for the establishment of a close connection with Tibet, Nepal, Bhutan, and Sikkim. The colonization brought a positive change regarding the black tea industry development. The British geographical botanists were not in favor of Darjeeling for tea cultivation during the early stage. However, the Dr. Campbell experiment proved that Darjeeling is the best place for Chinese tea seeds. His experiment helped in the development of commercial tea plantations and industry in Darjeeling. The climate and soil of Darjeeling were the crucial factors that provided the world-famous and distinctive flavored black tea. Most of the planters and entrepreneurs in Darjeeling were Scottish and British. The labour migrated for the development of the black tea industry from Nepal and several effective land policies were announced by the British government. These policies were much in favor of the expansion of the tea industry. The labour migration extended the Darjeeling population from 25 families to 20,000 people up to 1877 . The skills and knowledge of tea processing were transferred from China through the British East India Company and these were employed in Darjeeling. At the early stage, all the black tea-making steps were done by hand but during the 1870s, the industrial revolution was accrued and the tea rolling, sorting, and drying processes were mechanized to reduce the labour demand and improve the quality of the final tea product. With the establishment of the tea industry in Darjeeling, it was recognized to develop the infrastructure for its market extension. Therefore, road and railway infrastructure was developed for the improvement of the tea trade, labour division in tea estates, and technical development. Consequently, the British Empire initiated the black tea industry in Darjeeling and brought a great change in the tea plantation industry in terms of mechanical innovations in tea machinery, road and railway construction, land and labour availability. These initiatives enabled the Darjeeling black tea industry to extend its business to Europe and maintain its reputation in the world tea market.

\section{Acknowledgements}

The author extends her appreciation to the CAS-TWAS Presidential Fellowship authorities for the scholarship award and financial support during Ph.D. research studies at the University of Science and Technology of China.

\section{Conflicts of Interest}

The author declares no conflicts of interest regarding the publication of this paper.

\section{References}

Ahuja, P., Gulati, A., Singh, R., Sud, R., \& Boruah, R. (2013). Science of Tea Technology. 
Scientific Publishers

Behal, R. P., \& Mohapatra, P. P. (1992). “Tea and Money versus Human Life”: The Rise and Fall of the Indenture System in the Assam Tea Plantations 1840-1908. The Journal of Peasant Studies, 19, 142-172. https://doi.org/10.1080/03066159208438491

Besky, S. (2007). Rural Vulnerability and Tea Plantation Migration in Eastern Nepal and Darjeeling.

Besky, S. (2008). Can a Plantation Be Fair? Paradoxes and Possibilities in Fair Trade Darjeeling Tea Certification. Anthropology of Work Review, 29, 1-9. https://doi.org/10.1111/j.1548-1417.2008.00006.x

Besky, S. (2014). The Darjeeling Distinction: Labor and Justice on Fair-Trade Tea Plantations in India (Vol. 47). Univ. of California Press.

Bhattacharya, N. (2012). Contagion and Enclaves: Tropical Medicine in Colonial India. Liverpool University Press. https://doi.org/10.5949/UPO9781846317835

Bhattacharya, N. S. (2007). Disease and the Practices of Settlement in a Plantation Economy: Medicine and Healthcare in Darjeeling and Duars, 1860-1947. University of London.

Bhutia, S. (2016). Darjeeling Tea Industry: A Geographical Perspective on Production, Development, Promotion and Prospects. Khoj: An International Peer Reviewed Journal of Geography, 3, 84-96. https://doi.org/10.5958/2455-6963.2016.00009.6

Bose, S. P. (2018). Growth and Development of Tea Industry in Darjeeling: Colonial Period. International Journal of Research, 7, 15-17.

Christison, G. (1895). Darjeeling, Tea Planting In. RSA Journal, 44, 624.

Dash, A. J. (1947). Bengal District Gazetteers: Darjeeling. West Bengal Government Publication.

Dozey, E. (1922). A Concise History of the Darjeeling District since 1835.

Dubrin, B. (2012). Tea Culture: History, Traditions, Celebrations, Recipes \& More: History, Traditions, Celebrations, Recipes \& More. Charles Bridge Publishing.

Ellis, M., Coulton, R., \& Mauger, M. (2015). Empire of Tea: The Asian Leaf that Conquered the World. Reaktion Books.

Fortune, R. (1852). A Journey to the Tea Countries of China: Including Sung-Lo and the Bohea Hills; with a Short Notice of the East India Company's Tea Plantations in the Himalaya Mountains. John Murray. https://doi.org/10.5962/bhl.title.96218

Griffiths, P. (1967). The History of the Indian Tea Industry. Weidenfeld and Nicolson.

Gupta, R. D. (1992). Plantation Labour in Colonial India. The Journal of Peasant Studies, 19, 173-198. https://doi.org/10.1080/03066159208438492

Hall, N. (2000). The Tea Industry. Elsevier.

Hathorn, J. G. (1863). A Hand-Book of Darjeeling: With Brief Notes on the Culture and Manufacture of Tea, and Rules for the Sale of Unassessed Waste Lands. Etc. RC Lepage \& Company.

Hooker, J. D. (1891). Himalayan Journals: Or, Notes of a Naturalist in Bengal, the Sikkim and Nepal Himalayas, the Khasia Mountains, \& C (Vol. 32). Ward Lock. https://doi.org/10.5962/bhl.title.145729

Kati, R. (2015). Darjeeling: The Colorful History and Precarious Fate of the World's Greatest Tea. Reed Business Information.

Khasnobish, S. (2016). Socio-Economic and Political Transition of Darjeeling Terai (18641994). University of North Bengal. 
Khatun, H. (2013). Business and Business Communities of Darjeeling Sub-Division from 1835 to 1962: A Historical Study. University of North Bengal.

Khawas, V. (2011). Status of Tea Garden Labourers in Eastern Himalaya: A Case of Darjeeling Tea Industry. In M. Desai, \& S. Mitra (Eds.), Cloud, Stone and the Mind: The People and Environment of Darjeeling Hill Area (pp. 1-19). ICIMOD online digital library.

Koehler, J. (2015). Darjeeling. A History of the World's Greatest Tea. Bloomsbury Publishing.

Lss, O. M. (1907). Darjeeling District Gazetteer. Gyan Publication.

Malley, L. O. (1999). Bengal District Gazetteer: Darjeeling. Concept Publishing Company.

Martin, L. C. (2011). Tea: The Drink that Changed the World. Tuttle Publishing.

Maude, F. C., Davison, W., \& Haswell, C. H. (1869). Tea Cultivation in India. The Journal of the Society of Arts, 17, 291-310.

Mukherjee, S. (1976). Emergence of Bengalee Entrepreneurship in Tea Plantation in a Bengal District, 1879-1933. The Indian Economic \& Social History Review, 13, 487-505. https://doi.org/10.1177/001946467601300403

O’Malley, L. S. S. (1907). Bengal District Gazetteers: Palamau. Bengal Secretariat Book Depot.

O’Malley, L. S. S. (1910). Bengal District Gazetteers: Santal Parganas (Vol. 38). Concept Publishing Company.

Planter, A. (1888). Notes on Tea in Darjeeling. Scotch Mission Orphanage Press.

Rai, M. B. (2012). Birth of Darjeeling as a Hill Station. Central India Journal of Historical and Archaeological Research, 1, 171-174.

Rai, S. (2015). Plantation Industry of Darjeeling Region: A Historical Study. Ph.D. Thesis, Sikkim University.

Rathaur, K. R. S. (2001). British Gurkha Recruitment: A Historical Perspective. Voice of History, 16, 19-24. https://doi.org/10.3126/voh.v16i2.74

Rose, S. (2010). For All the Tea in China: How England Stole the World's Favorite Drink and Changed History. Penguin.

Roy, S. (2011). Historical Review of Growth of Tea Industries in India: A Study of Assam Tea. In The International Conference on Social Science and Humanity (pp. 116-170). IACSIT Press.

Roy, S., \& Hannam, K. (2013). Embodying the Mobilities of the Darjeeling Himalayan Railway. Mobilities, 8, 580-594. https://doi.org/10.1080/17450101.2012.745695

Saberi, H. (2010). Tea: A Global History. Reaktion Books.

Sarkar, T. (2014). Colonizing Darjeeling Forest without Indigenous Resistance: An Overview of Colonial Darjeeling.

Sen, S. (2010). Commercial Recruiting and Informal Intermediation: Debate over the Sardari System in Assam Tea Plantations, 1860-1900. Modern Asian Studies, 44, 3-28. https://doi.org/10.1017/S0026749X09990047

Sharma, J. (2006). British Science, Chinese Skill and Assam Tea: Making Empire's Garden. The Indian Economic \& Social History Review, 43, 429-455. https://doi.org/10.1177/001946460604300402

Sharma, J. (2009). "Lazy” Natives, Coolie Labour, and the Assam Tea Industry. Modern Asian Studies, 43, 1287-1324. https://doi.org/10.1017/S0026749X08003831

Sharma, K. (2003). Tea Plantation Workers in a Himalayan Region. Mittal Publications. 
Tirkey, L. P. (2005). Tea Plantations in the Darjeeling District, India: Geo-Ecological and Socio-Economic Impacts in Post-Independence Period.

Ukers, W. H. (1935). All about Tea (Vol. 1). Tea and Coffee Trade Journal Company.

Wallis-Tayler, A. J. (1900). Tea Machinery, and Tea Factories: A Descriptive Treatise on the Mechanical Appliances Required in the Cultivation of the Tea Plant and the Preparation of Tea for the Market. C. Lockwood and Son.

Willson, K. C., \& Clifford, M. N. (2012). Tea: Cultivation to Consumption. Springer Science $\&$ Business Media.

Wong, L. W.-C. (2007). Translators and Interpreters during the Opium War between Britain and China (1839-1842). In Translating and Interpreting Conflict (pp. 41-57). Brill Rodopi. https://doi.org/10.1163/9789401204385 005 